ORIGINAL ARTICLE

\title{
Optimization of Polymerase Chain Reaction for Detection of Clostridium botulinum Type $C$ and $D$ in Bovine Samples
}

\author{
V. Prévot ${ }^{1}$, F. Tweepenninckx ${ }^{1}$, E. Van Nerom ${ }^{1}$, A. Linden ${ }^{2}$, J. Content ${ }^{1}$ and A. Kimpe ${ }^{1}$ \\ 1 Pasteur Institute of Brussels, Rue Engeland 642, B1180 Bruxelles, Belgium \\ ${ }^{2}$ Faculté de Médecine Vétérinaire, BAT. B43 Bactériologie et pathologie des maladies bactériennes, University of Liège, Boulevard de Colonster \\ 20, 4000 Liège, Belgium
}

Keywords:

Botulism; botulinum toxin type C/D;

polymerase chain reaction

\section{Correspondence: \\ V. Prévot. Pasteur Institute of Brussels, Rue Engeland 642, B1180 Bruxelles, Belgium. \\ Tel.: 0032 (0)2 64437 30; \\ Fax: 0032 (0)2 37333 15; \\ E-mail: vanyabestien@gmail.com}

Received for publication June 4, 2007

\begin{abstract}
Summary
Botulism is a rare but serious paralytic illness caused by a nerve toxin that is produced by the bacterium Clostridium botulinum. The economic, medical and alimentary consequences can be catastrophic in case of an epizooty. A polymerase chain reaction (PCR)-based assay was developed for the detection of C. botulinum toxigenic strains type $\mathrm{C}$ and $\mathrm{D}$ in bovine samples. This assay has proved to be less expensive, faster and simpler to use than the mouse bioassay, the current reference method for diagnosis of $C$. botulinum toxigenic strains. Three pairs of primers were designed, one for global detection of C. botulinum types $\mathrm{C}$ and $\mathrm{D}$ (primer pair $\mathrm{Y}$ ), and two strain-specific pairs specifically designed for types $\mathrm{C}$ (primer pair VC) and D (primer pair VD). The PCR amplification conditions were optimized and evaluated on 13 bovine and two duck samples that had been previously tested by the mouse bioassay. In order to assess the impact of sample treatment, both DNA extracted from crude samples and three different enrichment broths (TYG, CMM, CMM followed by TYG) were tested. A $100 \%$ sensitivity was observed when samples were enriched for 5 days in CMM followed by 1 day in TYG broth. False-negative results were encountered when $C$. botulinum was screened for in crude samples. These findings indicate that the current PCR is a reliable method for the detection of C. botulinum toxigenic strains type $\mathrm{C}$ and $\mathrm{D}$ in bovine samples but only after proper enrichment in CMM and TYG broth.
\end{abstract}

\section{Importance of the paper's findings for a non-specialist:}

1. Developing a fast diagnosis method for botulism.

2. To be able to prevent the disease.

3. Reduce massive economic losses and public health risk whenever contaminated meat or dairy products enter the food chain.

\section{Introduction}

Botulism is a deadly disease of humans and animals caused by the neurotoxins produced by the anaerobic bacteria Clostridium botulinum. These neurotoxins (BoNT) are considered to be the most potent of all bacterial toxins
(Lamanna, 1959). In their active form, they consist of two subunits: a heavy chain $(100 \mathrm{kDa})$ and a light chain $(50 \mathrm{kDa})$ which are held together by a disulphide bridge (Niemann, 1991). Their mode of action relies on blocking the release of the acetylcholine neurotransmitter at the cholinergic synapses resulting in neuroparalytic disease that can lead to death (DasGupta, 1990). BoNTs are categorized into seven different types (A to $G$ ) according to their antigenic properties (Niemann, 1991).

Bovines are principally susceptible to type $\mathrm{D}$ toxin; however, they may also be affected by types C, B and rarely $\mathrm{A}$. They are usually toxin-infected when grazing poultry litter-contaminated pastures. However, in developing countries, these animals may suffer from hypophosphorous conditions and get infected by grazing 
spore-contaminated ground or carcasses (Carlier et al., 2001; Afssa, 2002).

The most important clinical signs of botulism in cattle include loss of tongue tone, decreased upper eyelid and tail tone, dilated pupils, dysphagia, and decreased ruminal motility (Whitlock, 1999). Whenever intoxication occurs in intensively farmed animals, high mortality rates can be observed (Abbitt et al., 1984; Trueman et al., 1992; Martin, 2003). Abbitt et al. (1984) found C. botulinum type $\mathrm{D}$ intoxication to be responsible for the death of 42 of 67 lactating cows in a south-east Texas dairy herd over an 11-day period. The economical, medical and alimentary consequences can be catastrophic in case of an epizooty. One gram of pure toxin dispersed in the food could kill 400000 adult cows (Galey et al., 2000).

Symptoms alone are often insufficient to make a diagnosis of botulism and a laboratory confirmation is required. Because of its high sensitivity, the mouse bioassay including the identification of the responsible BoNT by (sero) neutralization, still remains the standard method in botulism diagnostics (Shone et al., 1985; Doellgast et al., 1993). However, animal testing remains highly disapproved and non-specific mouse mortality can blur the diagnosis (Szabo et al., 1994a).

Treatment of bovine botulism is symptomatic and supportive but not curative. Treating the animal with antitoxins only prevents progression of the disease and is considered only for animals of great commercial value (Kirk and Adaska, 1998; OVF- Office vétérinaire fédéral, 2002).

In order to prevent botulism epizootic spread both preventative measures and rapid detection of the causative agent are of immense importance. In this respect, polymerase chain reaction (PCR) seems to be a diagnostic method with major advantages including rapid, easy and cheap methodology.

The application of PCR for the detection of neurotoxin genes has been successful for several different BoNT types (A, B, C, D, E and F) (Fach et al., 1993, 1995, 2002; Franciosa et al., 1994, 1996; Szabo et al., 1994a,b; Takeshi et al., 1996; Aranda et al., 1997; Braconnier et al., 2001; Dahlenborg et al., 2001; Lindström et al., 2001; Chaffer et al., 2006). Sensitivity is high; it can detect as little as 35 clostridial bacteria in a sample. However, detection limits appear to be dependent on the sample type (Wictome and Shone, 1998). This can be attributed to the presence of PCR inhibitors and other bacterial species in the samples (Fach et al., 1993). Therefore, PCR is considered highly sensitive when used for detection of BoNT genes in pure cultures in contrast to the detection directly in crude samples where sensitivity cannot be guaranteed without prior culture enrichment (Wictome and Shone, 1998).
With the recent achievements in the field of PCR detection of BoNT genes, we aimed at creating a highly specific, sensitive, quick and cheap method for the diagnosis of C. botulinum types $\mathrm{C}$ and $\mathrm{D}$ in bovine samples. In this light, we designed three sets of primers, optimized the PCR conditions, tested the optimized conditions in bovine samples and compared these results with the standard method. Testing of crude samples as well as different enrichment broths was also incorporated.

\section{Materials and Methods}

Bacterial strains

A total of 26 reference strains (15 C. botulinum and 11 other Clostridium species) were included in this study (Table 1). All reference strains were tested for BoNT production in the mouse bioassay as described below.

Sixteen clinical and field samples were collected from suspected cases (liver, stomach contents, kidney, brain and feed) (Table 1). Thirteen of these 16 samples tested positive for toxin production in the mouse bioassay. The remaining three samples tested negative in the same assay and were used as negative controls.

\section{Mouse bioassay}

All procedures with animals were carried out in accordance to appropriate humane methods. Swiss OF1 conventional mice were used. Breeding was performed in the breeding facilities of the Pasteur Institute, agreement number LA2230389. Mice were feed ad libitum with commercial pellets. Temperature was kept at $21^{\circ} \mathrm{C}$, ventilation at 15 refreshments per hour and light regimen was of $12 \mathrm{~h}$ light/12 $\mathrm{h}$ dark. Cages were of type II long mouse cages: height $=16 \mathrm{~cm}$, surface $=21 \times 37 \mathrm{~cm}$, with 10 mice per cage. Mice were used when they reached a weight of about $20 \mathrm{~g}$.

The mouse lethality test was performed as described previously (Kautter and Solomon, 1977). Briefly, after 5 days of anaerobic incubation in cooked meat medium (CMM) (Difco BD, Erembodegem-Aalst, Belgium) (Quagliaro, 1977) at $37^{\circ} \mathrm{C}, 2 \mathrm{ml}$ of enrichment culture were filtered over a $0.22 \mu \mathrm{m}$ Millipore filter (MillexGP, Millipore, Bruxelles, Belgium). A volume of $0.4 \mathrm{ml}$ of filtered solution was subsequently injected intraperitoneally into mice (two mice per sample). For 4 days, the mice were inspected for clinical symptoms of botulism (pinching of the waist, laboured breathing, paralysis and death). The presence and type of botulinum toxin was confirmed by an in vivo seroneutralization test in mice. Therefore, $225 \mu \mathrm{l}$ of specific botulinum antitoxins (Centre of Disease Control, Atlanta, GA, USA) were added to $900 \mu \mathrm{l}$ of filtered culture medium and incubated for $30 \mathrm{~min}$ at $37^{\circ} \mathrm{C}$. 


\begin{tabular}{|c|c|c|c|c|c|c|}
\hline & \multirow[b]{2}{*}{ Name } & \multirow[b]{2}{*}{ Origin } & \multirow{2}{*}{$\begin{array}{l}\text { Mouse } \\
\text { bioassay }\end{array}$} & \multicolumn{3}{|c|}{ Set of primers } \\
\hline & & & & Y & VC & VD \\
\hline \multirow{16}{*}{$\begin{array}{l}\text { Routine } \\
\text { samples }\end{array}$} & 03В019 & Bovine liver & $D^{a}$ & $\sqrt{b}^{\mathrm{b}}$ & $x c$ & $\sqrt{ }$ \\
\hline & $03 B 020^{d}$ & Bovine feed & $\mathrm{D}$ & $\sqrt{ }$ & $\times$ & $\sqrt{ }$ \\
\hline & $03 B 021$ & Bovine stomach contents & $\mathrm{D}$ & $\sqrt{ }$ & $x$ & $\sqrt{ }$ \\
\hline & $03 B 027$ & Bovine stomach contents & $\mathrm{D}$ & $\sqrt{ }$ & $x$ & $\sqrt{ }$ \\
\hline & 03В030 & Bovine stomach contents & $\mathrm{D}$ & $\sqrt{ }$ & $\times$ & $\sqrt{ }$ \\
\hline & $03 \mathrm{~B} 033$ & Bovine stomach contents & D & $\sqrt{ }$ & $\times$ & $\sqrt{ }$ \\
\hline & 03В038 & Bovine liver + kidney + brain & $\mathrm{D}$ & $\sqrt{ }$ & $x$ & $\sqrt{ }$ \\
\hline & 03В039 & Bovine stomach contents & D & $\sqrt{ }$ & $\times$ & $\sqrt{ }$ \\
\hline & $03 B 041$ & Bovine liver + stomach contents & $\mathrm{D}$ & $\sqrt{ }$ & $x$ & $\sqrt{ }$ \\
\hline & 03B042 & Bovine liver & $\mathrm{D}$ & $\sqrt{ }$ & $x$ & $\sqrt{ }$ \\
\hline & 03B111 & Bovine liver & $\mathrm{D}$ & $\sqrt{ }$ & $x$ & $\sqrt{ }$ \\
\hline & $03 B 113$ & Bovine liver & $\mathrm{D}$ & $\sqrt{ }$ & $x$ & $\sqrt{ }$ \\
\hline & 05B134 & Bovine liver & $\mathrm{D}$ & $\sqrt{ }$ & $x$ & $\sqrt{ }$ \\
\hline & 05B159 & Bovine liver & $-^{\mathrm{e}}$ & $\times$ & $\times$ & $\times$ \\
\hline & 05B166 & Duck Liver & - & $\times$ & $x$ & $\times$ \\
\hline & 05B167 & Duck Liver & - & $\times$ & $\times$ & $x$ \\
\hline \multirow{26}{*}{$\begin{array}{l}\text { Reference } \\
\text { strains }\end{array}$} & 041 & C. botulinum A (CIP 104.310$)$ & $A$ & $\times$ & $x$ & $\times$ \\
\hline & $04 \mathrm{~V}$ & C. botulinum A (ATCC 3502) & A & $\times$ & $\times$ & $\times$ \\
\hline & $04 \mathrm{VI}$ & C. botulinum A (ATCC 19397) & A & $\times$ & $x$ & $\times$ \\
\hline & 971 & C. botulinum $B(\mathrm{IPB})^{\mathrm{h}}$ & B & $\times$ & $\times$ & $\times$ \\
\hline & $04 \mathrm{IV}$ & C. botulinum B (NCTC 7273) & B & $\times$ & $\times$ & $\times$ \\
\hline & $05 e$ & C. botulinum B (IPB) & B & $\times$ & $x$ & $x$ \\
\hline & $04 \|$ & C. botulinum C (CIP 104.983) & C & $\sqrt{ }$ & $\sqrt{ }$ & $x$ \\
\hline & 981 & C. botulinum C (IPB) & $C$ & $\sqrt{ }$ & $\sqrt{ }$ & $x$ \\
\hline & $02 \|$ & C. botulinum C (IPB) & C & $\sqrt{ }$ & $\sqrt{ }$ & $\times$ \\
\hline & $02 \mathrm{~V}$ & C. botulinum D (IPB) & D & $\sqrt{ }$ & $\times$ & $\sqrt{ }$ \\
\hline & $02 \mathrm{VI}$ & C. botulinum D (IPB) & $\mathrm{D}$ & $\sqrt{ }$ & $x$ & $\sqrt{ }$ \\
\hline & $04 \mid I I$ & C. botulinum D (CIP 105.256) & D & $\sqrt{ }$ & $\times$ & $\sqrt{ }$ \\
\hline & $05 p$ & C. botulinum E (NCTC 08266) & $E$ & $\times$ & $x$ & $\times$ \\
\hline & 050 & C. botulinum F (NCTC 10281) & $\mathrm{F}$ & $\times$ & $\times$ & $\times$ \\
\hline & 051 & C. novii A (NCTC 13029) & A & $\times$ & $\times$ & $\times$ \\
\hline & $05 a$ & C. sordelii (IPB) & - & $\times$ & $x$ & $\times$ \\
\hline & 05b & C. difficile (IPB) & - & $\times$ & $\times$ & $\times$ \\
\hline & $05 c$ & C. bifermentans (IPB) & - & $\times$ & $\times$ & $\times$ \\
\hline & $05 c$ & C. difficile (IPB) & - & $\times$ & $x$ & $x$ \\
\hline & $05 f$ & C. fallax (IPB) & - & $\times$ & $\times$ & $\times$ \\
\hline & $05 \mathrm{~g}$ & C. perfringens (IPB) & - & $\times$ & $\times$ & $\times$ \\
\hline & $05 k$ & C. sporogenes (NCTC 13020) & - & $\times$ & $\times$ & $\times$ \\
\hline & $05 \mathrm{~m}$ & C. butyricum (NCTC 07423) & - & $\times$ & $\times$ & $\times$ \\
\hline & $05 n$ & C. hastiforme (NCTC 11832) & - & $\times$ & $\times$ & $\times$ \\
\hline & 801 & C. tetani (ATCC 10779) & - & $\times$ & $\times$ & $\times$ \\
\hline & $02 x$ & C. sporogenes (IPB) & - & $\times$ & $\times$ & $\times$ \\
\hline
\end{tabular}

Table 1. PCR and mouse bioassay results for the reference and routine samples

${ }^{\mathrm{a} C}$. botulinum type detected.

${ }^{\mathrm{b}}$ Fragment amplified with the expected size.

'No amplification.

${ }^{d}$ In italic: samples that are not bovine.

${ }^{\mathrm{e}}$ Negative result.

${ }^{f} \mathrm{CIP}$, Collection de I'Institut Pasteur, Paris, France.

${ }^{9}$ ATCC, American Type Culture Collections, Rockville, MD, USA.

$\mathrm{h}_{\mathrm{IPB}}$, Strain isolated at the Institut Pasteur de Bruxelles, Brussels, Belgium.

'NCTC, National Collection of Type Cultures, London, UK. 
Table 2. Tested culture methods

\begin{tabular}{|c|c|c|c|c|}
\hline \multirow[b]{2}{*}{ Name } & \multirow[b]{2}{*}{ Description } & \multicolumn{3}{|c|}{$\%$ of positive detections } \\
\hline & & Y & VC & VD \\
\hline TYG & Culture in TYG ${ }^{a}$ & 36 & 0 & 82 \\
\hline CMM & Culture in $\mathrm{CMM}^{\mathrm{b}}$ & 0 & 0 & 0 \\
\hline CMM.10 min & Culture in $\mathrm{CMM}$ heated $10^{\prime}$ at $80^{\circ} \mathrm{C}$ & 0 & 0 & 0 \\
\hline CMM.E & 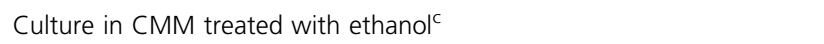 & 0 & 0 & 0 \\
\hline CMM.E.10 min & Culture in $\mathrm{CMM}$ heated $10^{\prime}$ at $80^{\circ} \mathrm{C}$ and treated with ethanol & 0 & 0 & 0 \\
\hline TYG $\leftarrow$ CMM & Culture in TYG inoculated with a culture of CMM & 100 & 100 & 100 \\
\hline TYG $\leftarrow$ CMM.10 min & Culture in TYG inoculated with a culture of $\mathrm{CMM}$ heated $10^{\prime}$ at $80^{\circ} \mathrm{C}$ & 100 & 100 & 100 \\
\hline TYG $\leftarrow C M M . E$ & Culture in TYG inoculated with a culture of CMM treated with ethanol & 100 & 100 & 100 \\
\hline
\end{tabular}

The last column gives the percentage of positive samples (tested in the mouse bioassay) that were detected positive by PCR for each type of culture and each primer.

${ }^{\mathrm{a}}$ All cultures in TYG were performed overnight at $37^{\circ} \mathrm{C}$.

${ }^{\mathrm{b}}$ All cultures in $\mathrm{CMM}$ were performed for 5 days at $37^{\circ} \mathrm{C}$.

${ }^{\mathrm{C}}$ Treatment with ethanol at $50 \%(\mathrm{v} / \mathrm{v})$ for $30 \mathrm{~min}$ at $37^{\circ} \mathrm{C}$.

A volume of $0.5 \mathrm{ml}$ was then injected intraperitoneally into mice. The animals were checked for symptoms as described above.

\section{Culture methods}

For PCR optimization stored reference strains were grown under anaerobic conditions in CMM broth for 5 days at $37^{\circ} \mathrm{C}$ followed by an overnight enrichment under similar conditions in trypticase yeast extract glucose (TYG) medium (Sebald and Petit, 1994).

Clinical and field samples were grown in various media (Table 2). Prior to inoculation, some cultures were either treated with ethanol, heat shocked for $10 \mathrm{~min}$ at $80^{\circ} \mathrm{C}$ or both to enhance $C$. botulinum recovery.

\section{DNA extraction}

DNA extractions were performed with the DNA extraction Kit GenElute ${ }^{\mathrm{TM}}$ Bacterial Genomic DNA Kit (Sigma, Bornem, Belgium). Briefly, a volume of $1.8 \mathrm{ml}$ of TYG culture was centrifuged at $16060 \mathrm{~g}$. Cell pellets were lysed with $200 \mu \mathrm{l}$ of a lysozyme solution $(45 \mathrm{mg} / \mathrm{ml})$ and subsequently treated with $20 \mu \mathrm{l}$ of RNase A for $3 \mathrm{~min}$ at room temperature. When extractions were made directly from the sample, $0.25 \mathrm{~g}$ was grinded with lysozyme solution and treated as described above.

The solution was incubated at $37^{\circ} \mathrm{C}$ for $30 \mathrm{~min}$. After addition of $20 \mu \mathrm{l}$ of proteinase $\mathrm{K}$ and $200 \mu \mathrm{l}$ of lysis solution the mix was incubated for $10 \mathrm{~min}$ at $55^{\circ} \mathrm{C}$. The Sigma binding columns were prepared by adding $500 \mu \mathrm{l}$ of column preparation solution and centrifuged at $13000 \mathrm{rpm}$. The elute was discarded. Thereafter, a volume of $200 \mu \mathrm{l}$ of ethanol (100\%) was added to the lysate and mixed. The entire content was then transferred into the binding column and centrifuged at $6090 \mathrm{~g}$ for $1 \mathrm{~min}$. Subsequently, the DNA recovered on the column was washed twice with $500 \mu \mathrm{l}$ of wash solution 1 and $500 \mu \mathrm{l}$ of wash solution respectively at $8000 \mathrm{rpm}$ for $1 \mathrm{~min}$ and at $13000 \mathrm{rpm}$ for $3 \mathrm{~min}$. DNA was eluted with $200 \mu \mathrm{l}$ of elution solution and centrifuged at $8000 \mathrm{rpm}$ for $1 \mathrm{~min}$.

\section{PCR assay}

\section{Primer design}

The sequences of the different $C$. botulinum neurotoxin genes (BoNT/A, BoNT/B, BoNT/C, BoNT/D, BoNT/E, $\mathrm{BoNT} / \mathrm{F}$ BoNT/G and the tetanus neurotoxin) were retrieved from the National Centre for Biotechnology Information (http://www.ncbi.nlm.nih.gov). The primers were designed after alignment using the program WemBoss from the European Molecular Biology Network (http://www.embnet.org). The sequences and the locations of these primers as well as the expected amplicon sizes are listed in Table 3. One set was chosen in the most homologous regions of the sequences for BoNT/C and BoNT/D (primer set $\mathrm{Y}$ ). Two sets of primers (VC and VD) were chosen for the specific BoNT/C and BoNT/D detection, respectively. The primers were tested with the program AMPLIFY (version 1.2) for primer-dimer formation and specificity.

\section{PCR optimization}

Amplification was carried out in the GENEAmp ${ }^{\circledR}$ PCR system 2700 (Applied Biosystems, Lennik, Belgium). The cycling conditions were optimized in order to use all primers sets in a single run. For this, a variation of the annealing temperature from 40 to $65^{\circ} \mathrm{C}$ was tested as well as various concentrations of $\mathrm{MgCl}_{2}(1.5,2.5,3.5$ and $4.5 \mathrm{~mm})$. 
Table 3. Description of the primers

\begin{tabular}{|c|c|c|c|c|c|c|c|}
\hline Primer & $\begin{array}{l}\text { Primer } \\
\text { set }\end{array}$ & Sequences $5^{\prime}-3^{\prime}$ & $\begin{array}{l}\text { BoNT } \\
\text { type }\end{array}$ & $\begin{array}{l}\text { Position in the } \\
\text { BoNT gene } \\
\text { sequence }\end{array}$ & $\begin{array}{l}\text { Accession } \\
\text { number }\end{array}$ & $\begin{array}{l}\text { Corresponding } \\
\text { toxin chain }\end{array}$ & $\begin{array}{l}\text { Size of } \\
\text { amplicons }\end{array}$ \\
\hline cds2 & Y & tttatacgagaatgttcyg & $C$ and $D$ & $2343-2362$ & AB037166 AB012112 & $\mathrm{HC}^{\mathrm{a}}$ & $327 \mathrm{bp}$ \\
\hline cdas3 & & cattatatcctgatgtatcc & $C$ and $D$ & $2650-2670$ & & & \\
\hline $\operatorname{cs} 1.2$ & VC & tcctcgagttacaagcc & C & 182-199 & AB037166 & $L c^{b}$ & 169 bp \\
\hline cas2 & & caggaaagggtatatctg & C & $333-351$ & & & \\
\hline $\mathrm{ds} 2$ & VD & ttagactatacagcatccc & $\mathrm{D}$ & $495-514$ & AB012112 & $L c^{b}$ & $264 \mathrm{bp}$ \\
\hline das2 & & taacttgtggacgaatcc & D & $741-759$ & & & \\
\hline
\end{tabular}

${ }^{a}$ Heavy chain.

bight chain.

The sensitivity of the method was estimated with a large range of dilutions from $100 \mathrm{ng}$ to $10 \mathrm{ag}$ of the DNA from the reference strains (Table 1) in order to determine the lowest concentration allowing detection. The specificity of the primers was tested in the presence of DNA from other types of BoNT and with other Clostridia listed in Table 1.

The PCR cycling is a modification of the protocol described previously by Fach in 1993 (Fach et al., 1993). The cycling began with an initial step at $95^{\circ} \mathrm{C}$ for $15 \mathrm{~min}$ to activate the HotStart Taq polymerase (Eurogentec, Seraing, Belgium). Each following cycle consisted of a denaturation step at $94^{\circ} \mathrm{C}$ for $30 \mathrm{~s}$, an annealing step at $55^{\circ} \mathrm{C}$ for $30 \mathrm{~s}$, and an extension step at $72^{\circ} \mathrm{C}$ for $30 \mathrm{~s}$. This was repeated 40 times. A final step at $72^{\circ} \mathrm{C}$ for $10 \mathrm{~min}$ followed to complete extension.

Positive controls with DNA from reference strains and a negative control containing all reagents except DNA template were included during amplification. The amplified PCR products were visualized in $1.8 \%$ agarose gels (Agarose ultra Pure; GibcoBRL, Merelbeke, Belgium) and stained with ethidium bromide (molecular weight marker: Smart Ladder $\mathrm{SF}^{\mathrm{TM}}$; Eurogentec). After optimization, clinical samples were tested by PCR.

\section{Results}

\section{PCR optimization}

The optimal PCR conditions were set as follows: a final reaction volume of $50 \mu \mathrm{l}$ containing $25 \mu \mathrm{l}$ of Mix PCR

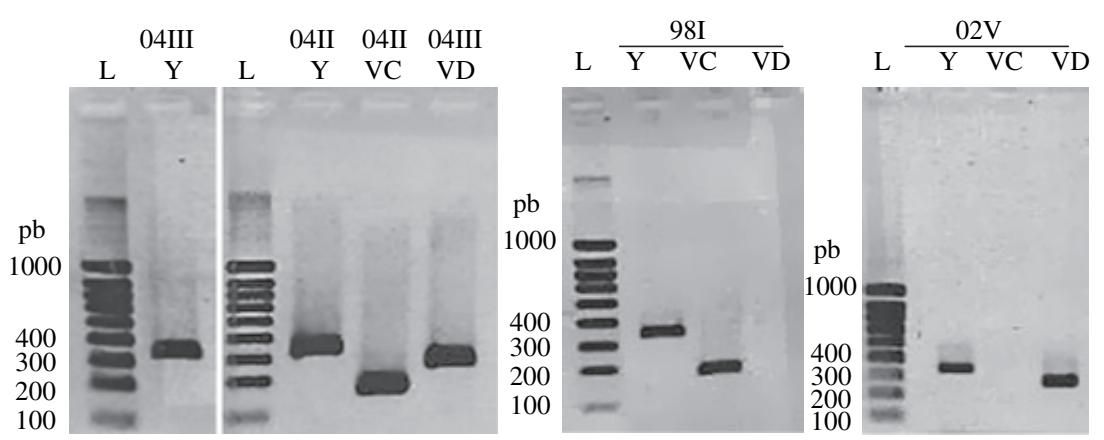

(Red'y'Star Mix from Eurogentec, PK-0073-02R), $3.5 \mathrm{~mm}$ of $\mathrm{MgCl}_{2}, \quad 0.5 \mu \mathrm{M}$ concentrations of each primer (Operon, Cologne, Germany) and $10 \mu \mathrm{l}$ of template (100 ng of sample DNA). The optimal annealing temperature was set at $55^{\circ} \mathrm{C}$. The lowest concentration of DNA detectable for primers $\mathrm{Y}, \mathrm{VC}$ and VD was set at $100 \mathrm{fg}$, $1 \mathrm{pg}$ and 10 fg respectively.

The specificity of the primers was confirmed. None of the other C. botulinum types and Clostridia tested were amplified with either of the three sets of primers (Fig. 1 shows some of the results). All C. botulinum type C strains tested positive for the amplification of a $327 \mathrm{bp}$ and $169 \mathrm{bp}$ DNA fragments when primers $\mathrm{Y}$ and VC were used, respectively. All C. botulinum type D strains were found positive for the amplification of a 327-bp fragment (primers Y) and a 264-bp fragment (primers VD) (Fig. 1). In order to confirm the results, most of the segments amplified in the PCR optimization were sequenced.

\section{Application of the optimized PCR in routine samples}

Sixteen routine samples enriched in CMM medium (5 days) followed by an overnight culture (16 h) in TYG broth were analysed by the mouse bioassay and subjected to molecular diagnosis by PCR amplification (Table 1 and Fig. 2).

Figure 2 shows the results of amplification of routine samples 03B019, 03B039 and 03B134 with primer set $\mathrm{Y}$, VC and VD. These three samples were tested positive for
Fig. 1. Results of the PCR optimization: amplification of reference samples with primer set Y, VC and VD. L, ladder; 04II, type $C ; 04 I I I$, type $D ; 98 I$, type C; 02V, type D. 
Fig. 2. Results of amplification of routine samples 03B019, 03B039 and 03B134 with primer set $Y, V C$ and VD. L, ladder.

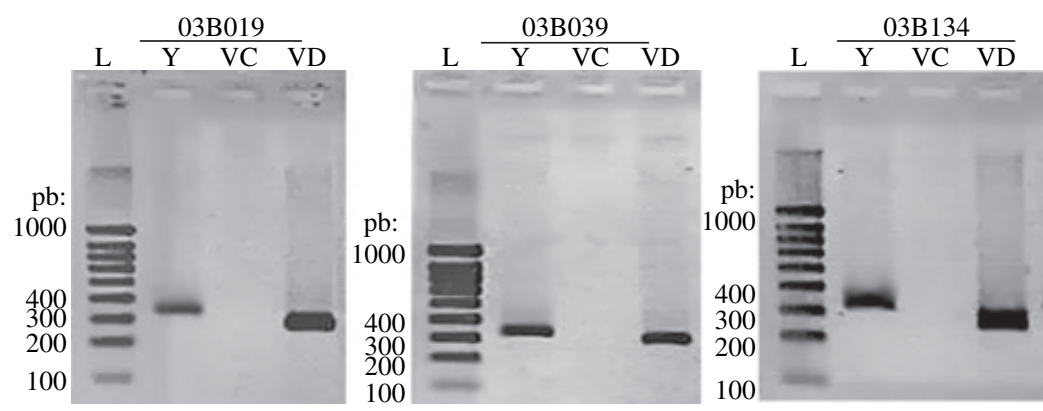

toxin production type $\mathrm{D}$ in the mouse bioassay, and pictures show that primers $\mathrm{Y}$ and VD amplify them. No pictures could be shown for sample amplification with primer set VC since we didn't dispose any natural positive bovine samples for $C$. botulinum type C.

Polymerase chain reaction testing confirmed the positive bioassay results of all 13 samples. Cross-reactivity between type $\mathrm{C}$ and $\mathrm{D}$ was not encountered. The three remaining samples that tested negative in the mouse bioassay were also found to be negative in PCR assay. Of the different culture methods used (Table 2), 5 days of enrichment in $\mathrm{CMM}$ at $37^{\circ} \mathrm{C}$ followed by overnight incubation in TYG at the same temperature proved to be the most appropriate. PCR performed on crude samples and other enrichment cultures were not reproducible. Only three and four positive results were confirmed in the PCR assay when crude samples or $16 \mathrm{~h}$ TGY enrichment were used, respectively. PCR results were also confirmed by sequencing.

\section{Discussion}

The prevention and rapid detection of bovine botulism is a worldwide problem. An epizooty can result in massive economic losses and public health could be at risk whenever contaminated meat or dairy products enter the food chain. In the search for rapid botulism detection methods, PCR has already proven its usefulness (Fach et al., 1993, 1995; Franciosa et al., 1994, 1996; Szabo et al., 1994a,b; Takeshi et al., 1996). However, as far as bovine samples are concerned, very little has been studied. In the studies performed by Fach et al. (1996) and Chaffer et al. (2006), PCR was used to optimize a diagnostic technique for bovine samples. Fach et al. (1996) employed a double PCR. They first amplified a fragment common to BoNT $\mathrm{C} 1$ and D, followed by a separate amplification based on two primers specifically for the latter toxin types. The primers were located in the N-terminal domain of the heavy chain, which is responsible for the translocation of the light chain into the cytosol. Enrichment of naturally contaminated animal and food samples was made in TYG for $48 \mathrm{~h}$. Fach et al. found a $89.4 \%$ correlation rate with the standard mouse bioassay and $4.3 \%$ false-negative results. In the study of Chaffer et al. (2006) the samples were enriched in fortified egg meat medium (FEM) for 5 days and their DNA was amplified with primers based on those of Takeshi et al. (1996). They were situated within the light chain of the neurotoxins (catalytic domain). For their bovine samples, they found 100\% correlation between the bio assay and their PCR. However, only six bovine samples were incorporated in this study.

In contrast to the PCR methods described above, we set up a new approach to confirm the presence of the entire BONT/C or D genes. For this, three new pairs of primers were designed: a general set situated in the heavy chain $(\mathrm{Y})$ and two specific sets of primers localized in the light chain of toxin type $\mathrm{C}(\mathrm{VC})$ and $\mathrm{D}(\mathrm{VD})$, respectively. The simultaneous detection of primer $\mathrm{Y}$ and primer VC or VD amplicons only endorse the presence of either two C. botulinum toxin genes, as both toxic activity (light chain) and binding/translocation (heavy chain) domain will be detected.

Bovine C. botulinum type $\mathrm{C}$ cases are rather rare in Belgium. They are more frequently encountered in countries that entail mixed bovine and avian husbandry like Australia and South Africa. PCR sensitivity and specificity for type BoNT/C was confirmed in our study using the reference strains; hence it is fair to assume that, under condition that recommended enrichments are made, bovine botulinum type $\mathrm{C}$ will be detectable. However the lack of natural positive bovine samples for C. botulinum type $\mathrm{C}$ did not allow us to confirm that bovine botulinum type $\mathrm{C}$ will be indeed detectable.

The primers designed and tested in this study proved to be highly specific and sensitive for the detection of BoNT/C and D genes. Results drew out of our PCR technique were concordant with those from the mouse bioassay and a $100 \%$ sensitivity level was reached. However, for this, samples required enrichment in CMM for 5 days followed by enrichment in TYG broth overnight. The application of the technique directly on crude samples and enrichment culture of just one night in TYG broth resulted in false-negative results. For these samples, our PCR hitherto remains inadequate. This could be due to a low concentration of target bacteria, cation concentration 
or even the presence of large numbers of concomitant bacteria, proteases, chelators or other Taq polymerase inhibitory factors remaining in the crude sample (Thomas et al., 1991; Wilson et al., 1991). These factors are variable according to sample origin and conservation conditions. Therefore, sample treatment as well as culture method, depend on sample nature and conservation status (Fach et al., 1993).

Internal amplification controls should be routinely included in diagnostic PCR to control inhibition by the sample material. So far reports on their use in the molecular diagnostics of $C$. botulinum are limited: Fach et al. (2002) developed a synthetic internal control (IC) that was able to coamplify the bont/A, bont/B, bont/E, and bont $/ \mathrm{F}$ genes in the same reaction. IC is a recombinant pMOS Blue plasmid DNA with $\mathrm{CB} 1$ and P261 primer-binding regions, flanking a DNA sequence of the chloramphenicol resistance gene $\left(\mathrm{Cm}^{\mathrm{r}}\right)$ from $\mathrm{Tn} 9$ (Fach et al., 2002).

In order to accelerate the rapidity of our PCR technique, it would be of interest to realize a reduction in or even an omission of sample enrichment time. In this light it would be necessary to find a technique that will eliminate all PCR inhibitors and impeding bacteria present in the sample. Different types of sample treatment (heat and/or ethanol) have shown to be useful for some samples but could not be extrapolated for others (F. Tweepenninckx, E. Van Nerom and V. Prévot, unpublished observations). We were unable to standardize sample treatment to be used systematically.

Unfortunately, until now no efficient selective media for isolation of C. botulinum are available (Fach et al., 2002). An alternative method to 'purify' samples has yet to be discovered. In this light, miscellaneous methods can be proposed: antibiotic treatment to eliminate contaminant bacteria (a mixture of cycloserine 1\%, sulfomethoxazole $1.9 \%$ and trimethoprim $0.1 \%$ is already used in some cases; Dezfulian et al., 1981); development of a matrix capable of eliminating the Taq polymerase inhibitors directly from the samples or refining methods permitting the recovery of merely $C$. botulinum DNA after extraction.

\section{Acknowledgements}

The authors will like to thank Dr Pablo Bifani and Dr Jean-Pierre Prévot for their constructive comments and also Mme Turneer. We are also thankful to the reviewers for their constructive suggestions that have significantly improved our manuscript.

\section{References}

Abbitt, B., M. J. Murphy, A. C. Ray, J. C. Reagor, A. K. Eugster, L. G. Gayle, H. W. Whitford, R. J. Sutherland, R. A.
Fiske, and J. Pusok, 1984: Catastrophic death losses in a dairy herd attributed to type D botulism. J. Am. Vet. Med. Assoc. 185, 798-801.

Afssa 2002: Rapport sur le botulisme d'origine aviaire et bovine. Agence française de sécurité sanitaire des aliments. Octobre 2002. Afssa, Nancy, France.

Aranda, E., M. M. Rodríguez, M. A. Asensio, and J. J. Córdoba, 1997: Detection of Clostridium botulinum types A, B, E and F in foods by PCR and DNA probe. Lett. Appl. Microbiol. 25, 186-190.

Braconnier, A., V. Broussolle, S. Perelle, P. Fach, C. NguyenThe, and F. Carlin, 2001: Screening for clostridium botulinum type A, B, and $\mathrm{E}$ in cooked chilled foods containing vegetables and raw material using polymerase chain reaction and molecular probes. J. Food Prot. 64, 201-207.

Carlier, J. P., C. Henry, V. Lorin, and M. R. Popoff, 2001: Le botulisme en France à la fin du deuxième millénaire (19982000). Bulletin épidémiologique hebdomadaire no. 09/2001.

Chaffer, M., M. Baum, K. Grinberg, T. Molad, and D. Elad, 2006: Application of PCR for detection of Clostridium botulinum type D in bovine samples. J. Vet. Med. B 53, $45-47$.

Dahlenborg, M., E. Borch, and P. Rådström, 2001: Development of a combined selection and enrichment PCR procedure for Clostridium botulinum types B, E, and $\mathrm{F}$ and its use to determine prevalence in fecal samples from slaughtered pigs. Appl. Environ. Microbiol. 67, 4781-4788.

DasGupta, R. B., 1990: Structure and biological activity of botulinum neurotoxin. J. Physiol. 84, 220-228.

Dezfulian, M., L. M. McCroskey, C. L. Hatheway, and V. R. Dowell Jr, 1981: Selective medium for isolation of Clostridium botulinum from human feces. J. Clin. Microbiol. 13, 526-531.

Doellgast, G. J., M. X. Triscott, G. A. Beard, J. D. Bottoms, T. Cheng, B. H. Roh, M. G. Roman, P. A. Hall, and J. E. Brown, 1993: Sensitive enzyme-linked immunosorbent assay for detection of Clostridium botulinum neurotoxins A, B and E using signal amplification via enzyme-linked coagulation assay. J. Clin. Microbiol. 31, 2402-2409.

Fach, P., D. Hauser, J. P. Guillou, and M. R. Popoff, 1993: Polymerase chain reaction for the rapid identification of Clostridium botulinum type A strains and detection in food samples. J. Appl. Bacteriol. 75, 234-239.

Fach, P., M. Gibert, R. Griffais, J. P. Guillou, and M. R. Popoff, 1995: PCR and gene probe identification of botulinum neurotoxin A-, B-, E-, F-, and G-producing Clostridium spp. and evaluation in food samples. Appl. Environ. Microbiol. 61, 389-392.

Fach, P., M. Gibert, R. Griffais, and M. R. Popoff, 1996: Investigation of animal botulism outbreaks by PCR and standard methods. FEMS Immunol. Med. Microbiol. 13, 279-285.

Fach, P., S. Perelle, F. Dilasser, J. Grout, C. Dargaignaratz, L. Botella, J. M. Gourreau, F. Carlin, M. R. Popoff, and V. Broussolle, 2002: Detection by PCR-enzyme-linked immunosorbent assay of Clostridium botulinum in fish and 
environmental samples from a coastal area in northern France. Appl. Environ. Microbiol. 68, 5870-5876.

Franciosa, G., J. L. Ferreira, and C. L. Hatheway, 1994: Detection of type A, B, and E botulism neurotoxin genes in Clostridium botulinum and other Clostridium species by PCR: evidence of unexpressed type B toxin genes in type A toxigenic organisms. J. Clin. Microbiol. 32, 1911-1917.

Franciosa, G., L. Fenicia, C. Caldiani, and P. Aureli, 1996: PCR for detection of Clostridium botulinum type $\mathrm{C}$ in avian and environmental samples. J. Clin. Microbiol. 34, 882-885.

Galey, F. D., R. Terra, R. Walker, J. Adaska, M. A. Etchebarne, B. Puschner, E. Fisher, R. H. Whitlock, T. Rocke, D. Willoughby, and E. Tor, 2000: Type C botulism in dairy cattle from feed contaminated with a dead cat. J. Vet. Diagn. Invest. 12, 204-209.

Kautter, D. A., and H. M. Solomon, 1977: Collaborative study of a method for the detection of Clostridium botulinum and its toxins in foods. J. Assoc. Off. Anal. Chem. 60, 541-545.

Kirk, J., and J. Adaska, 1998: Botulism in Cattle. University of California, Davis, CA.

Lamanna, C., 1959: The most poisonous poison. Science 130, 763-772.

Lindström, M., R. Keto, A. Markkula, M. Nevas, S. Hielm, and H. Korkeala, 2001: Multiplex PCR assay for detection and identification of Clostridium botulinum types A, B, E, and F in food and fecal material. Appl. Environ. Microbiol. 67, 5694-5699.

Martin, S., 2003: Clostridium botulinum type D intoxication in a dairy herd in Ontario. Can. Vet. J. 44, 493-495.

Niemann, H., 1991: Molecular biology of clostridial neurotoxins. In: Alouf, J. E., and J. H. Freer (eds), Sourcebook of Bacterial Protein Toxins, pp. 303-348. Academic Press, New York.

OVF - Office vétérinaire fédéral 2002: Rapport 2001 sur les zoonoses. Magazine OVF

Quagliaro, D. A., 1977: An improved cooked meat medium for the detection of Clostridium botulinum. J. Assoc. Off. Anal Chem. 60, 563-569.
Sebald, M., and J. C. Petit, 1994: Méthodes de laboratoire. Bactéries anaérobies et leur identification. Institut Pasteur de Paris, Paris.

Shone, C., P. Wilton-Smith, N. Appleton, P. Hambleton, N. Modi, S. Gattey, and J. Melling, 1985: Monoclonal antibody-based immunoassay for type A Clostridium botulinum toxin is comparable to the mouse bioassay. Appl. Environ. Microbiol. 50, 63-67.

Szabo, E. A., J. M. Pemberton, A. M. Gibson, M. J. Eyles, and P. M. Desmarchelier, 1994a: Polymerase chain reaction for detection of Clostridium botulinum types A, B and E in food, soil and infant faeces. J. Appl. Bacteriol. 76, 539-545.

Szabo, E. A., J. M. Pemberton, A. M. Gibson, R. J. Thomas, P. R. Pascoe, and P. M. Desmarchelier, 1994b: Application of PCR to a clinical and environmental investigation of a case of equine botulism. J. Clin. Microbiol. 32, 1986-1991.

Takeshi, K., Y. Fujinaga, K. Inoue, H. Nakajima, K. Oguma, T. Ueno, H. Sunagawa, and T. Ohyama, 1996: Simple method for detection of Clostridium botulinum type A to F neurotoxin genes by ploymerase chain reaction. Microbiol. Immunol. 40, 5-11.

Thomas, E. J., R. K. King, J. Burchak, and V. P. Gannon, 1991: Sensitive and specific detection of Listeria monocytogenes in milk and ground beef with the polymerase chain reaction. Appl. Environ. Microbiol. 57, 2576-2580.

Trueman, K. F., R. E. Bock, R. J. Thomas, J. D. Taylor, P. A. Green, H. M. Roeger, and P. J. Ketterer, 1992: Suspected botulism in three intensively managed Australian cattle herds. Vet. Rec. 130, 398-400.

Whitlock, R. 1999: Botulism toxicosis of cattle. Proc. Annu Conf. Am. Assoc. Bovine Pract. 32, 45-53.

Wictome, M., and C. C. Shone, 1998: Botulism neurotoxins: mode of action and detection. Symp. Ser. Soc. Appl Microbiol. 27, 87-97.

Wilson, I. G., J. E. Cooper, and A. Gilmour, 1991: Detection of enterotoxigenic Staphylococcus aureus in dried skimmed milk: use of the polymerase chain reaction for amplification and detection of staphylococcal enterotoxin genes entB and entC1 and the thermonuclease gene nuc. Appl. Environ. Microbiol. 57, 1793-1798. 